\title{
Research on Factors Affecting Consumers' Purchase Intentions: Fresh Hema based on New Retail
}

\author{
Zhang Shuyuan \\ Center of Service Science and Engineering, School of \\ Management \\ Wuhan University of Science and Technology \\ Wuhan, China
}

\author{
Wei Hao \\ Center of Service Science and Engineering, School of \\ Management \\ Wuhan University of Science and Technology \\ Wuhan, China
}

\begin{abstract}
With the development of the deep-integrated new retail model "online + offline + logistics", the innovative operation mode of Fresh Hema adapts to the needs of the fresh market, and consumers' shopping experience is more valued. This paper takes the Fresh Hema consumer as the research object, and combines the characteristics of Fresh Hema operation to analyze the influence mechanism of consumers' purchase intention in the new retail mode. The results show the following indications: (1) Perceived value has a significant positive impact on purchase intention, indicating that the higher the perceived value of the customer, the stronger the purchase intention. (2)Service quality has a significant positive impact on perceived value and purchase intention. The impact of offline service quality on perceived value is the most significant, indicating that consumers pay more attention to the physical store shopping experience and are less sensitive to logistics services.(3)Perceived risk has a significant negative impact on perceived value and purchase intention, meaning that the lower the perceived risk, the more likely the purchase will be. On this basis, it proposes an optimization strategy for the current operation mode of Fresh Hema, which provides reference for the operation of Fresh Hema and other fresh merchants.
\end{abstract}

Keywords-Fresh hema; Purchase intention; Perceived value; Service quality; Perceived risk

\section{INTRODUCTION}

In October 2016, Mayun first put forward the concept of "new retail". On November11, 2016, the General Office of the State Council issued the "Opinions on Promoting the Innovation Transformation of Physical Retail" to guide the direction of "new retail" in the future[1].Since the establishment of Yiguo, the first fresh food e-commerce provider in China in October 2005, the fresh food market in China has undergone exploration, rapid development and reshuffle. According to iResearch statistics, in 2017, the turnover of China's fresh e-commerce market was approximately 139.13 billion yuan, an increase of $59.7 \%$ yearon-year. It is expected that the transaction volume in 2020 will be 313.23 billion yuan. The fresh market transaction size in 2013-2020 is shown in Figure 1.

Fresh Hema was the product of the development of the "new retail" industry. In August 2017, it was honorably listed among the top ten new retail enterprises in Harvard Business Review. The "supermarket + catering" business model was welcomed by consumers. Why it stands out among many fresh e-commerce providers, many scholars have studied it. Cao $\mathrm{Yu}$ and Liu Zhili (2017)[2] believe that Fresh Hema is the pioneer of "new retail". The innovative $\mathrm{O} 2 \mathrm{O}$ model has overturned traditional supermarkets and changed the competitive landscape of the fresh industry. Feng Shanshan (2017)[3] believes that Fresh Hema's restructured retail business model is the reason for success. Wang Yuanyuan, Shao Dan and Cui Zhao (2017)[4] analyzed the new retail model of Fresh Hema, and proposed an improvement strategy for single payment methods and poor customer experience. Therefore, this article concentrates on the perspective of consumers' purchase intention towards Fresh Hema. Through researche on the factors that affect consumers' purchase intention, this paper aims at improving the operation mode that meets consumers' needs, enhances the consumers' experience and provides reference for the operation of Fresh Hema and other fresh merchants. 


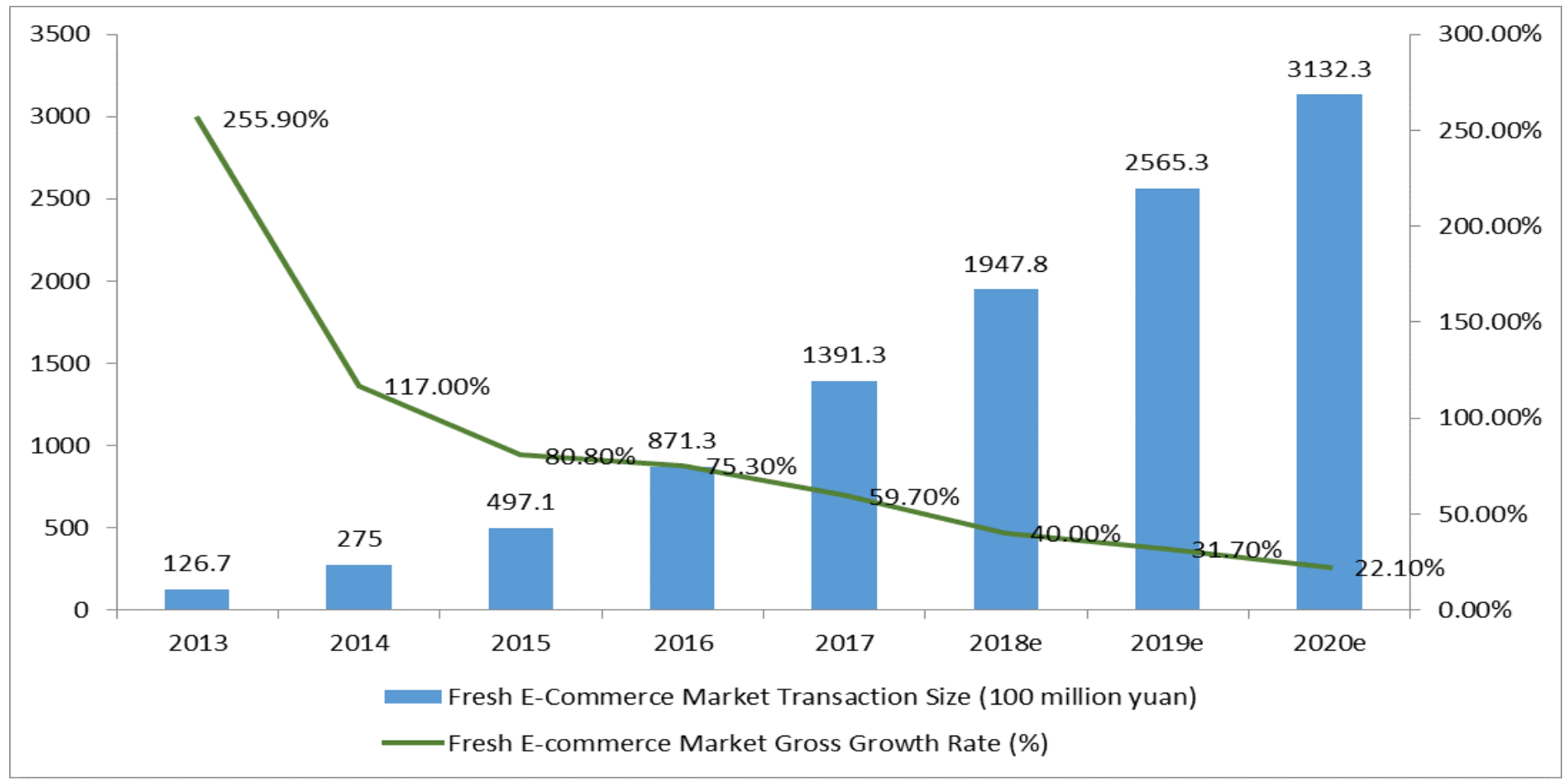

Source: iResearch, 2018 China's fresh energy e-commerce industry consumption insight report.

Fig. 1. China's Fresh E-commerce Market Transaction Scale from 2013 to 2020

\section{ANALYSIS ON FRESH HEMA 'S ENVIRONMENT}

Since its inception in 2016, Fresh Hema has 64 stores nationwide and is expected to have more than 100 stores nationwide this year. The rapid development of Fresh Hema is inseparable from the innovation of its operation mode, that is, the integration of "online + offline + logistics" and "supermarket + catering" mode.

"Online + offline + logistics" model is the combination of online, offline and logistics. Online consumers can place orders through the Fresh Hema APP; The offline store is not only a shopping place, but also a warehousing, sorting and distribution center; At the same time, logistics is a bridge connecting online and offline, online consumers enjoy 30 minutes free delivery within $3 \mathrm{~km}$.

The "Supermarket + Dining" mode is the front shop back store mode. Fresh Hema on the basis of traditional supermarkets, increased the dining area. In addition, seafood products also provide processing services. In March of this year, Shanghai Nanxiang Store launched a robotic restaurant, which realized the intelligent management from ordering to delivery. The SWOT analysis of Fresh Hema's environment is shown in Table 1.

\section{TABLE I. SWOT ANALYSIS}

\begin{tabular}{|c|c|c|}
\hline & $\begin{array}{l}\text { Strengths } \\
\text { 1.Online and offline integration } \\
\text { 2."Supermarket }+ \text { Dining" model } \\
\text { 3.Resource sharing, low procurement costs } \\
\text { 4.Electronic tags and in-store conveyor } \\
\text { belts reduce manual amount }\end{array}$ & $\begin{array}{l}\text { Weaknesses } \\
\text { 1.Must use APP to make payment } \\
\text { 2.High wear rate and high price positioning } \\
\text { 3.Dining area environment is noisy, poor } \\
\text { experience } \\
\text { 4.Delivery distance is limited }\end{array}$ \\
\hline $\begin{array}{l}\text { Opportunity } \\
\text { 1.Consumers are mainly young people, } \\
\text { with low price sensitivity, pursuing quality } \\
\text { and popularity } \\
\text { 2.Catering can increase consumers' time in } \\
\text { the store }\end{array}$ & $\begin{array}{l}\text { Opportunity-strength Strategies } \\
\text { 1.Develop a business strategy centered on } \\
\text { young people } \\
\text { 2.Grasping consumer preferences and } \\
\text { improving service quality }\end{array}$ & $\begin{array}{l}\text { Opportunity-weaknesses Strategies } \\
\text { 1.Adopt young people's favorite } \\
\text { consumption methods and high quality } \\
\text { 2. Improve catering quality and give } \\
\text { consumers a better experience }\end{array}$ \\
\hline $\begin{array}{l}\text { Threats } \\
\text { 1.There are many similar competitors } \\
\text { such as Yiguo, 7FRESH, etc. } \\
\text { 2. Expansion will increase costs, and price } \\
\text { increase will lose customers }\end{array}$ & $\begin{array}{l}\text { Threat-strength Strategies } \\
\text { 1. With the help of Ali online and offline } \\
\text { promotion } \\
\text { 2.Collaborate with local logistics providers } \\
\text { to appropriately reduce operating costs }\end{array}$ & $\begin{array}{l}\text { Threat-weaknesses Strategies } \\
\text { 1.Make up for deficiencies and stand out } \\
\text { from the same category } \\
\text { 2.Use big data to takeaway orders and } \\
\text { distribute to nearest stores }\end{array}$ \\
\hline
\end{tabular}




\section{LITERATURE REVIEW AND RESEARCH HYPOTHESIS}

\section{A. Perceived Value}

Perceived value refers to the difference between the perceived benefit and the cost paid by the consumer when acquiring the product or service, resulting in a subjective evaluation of the overall utility of the product or service[5]. Woodruff (1997)[6] believes that the perceived value of consumers is a kind of preference and evaluation, and it's good or bad depends on whether the shopping experience and expectations of consumers when purchasing products are consistent. Fan Xiucheng and Luo Haicheng (2003)[7] believe that customer perceived value is complex, influenced by functional value, emotional value and social value, as well as customer perceived income and perceived contribution. Wang Xiqiu (2005)[8] divides perceived value into three dimensions: economic value, functional value and psychological value, and is evaluated by the theory of fuzzy mathematics. It can be seen that the academic community has fully recognized the importance of consumer perceived value. The higher the perceived value of consumers is, the more favorable it is for enterprises to obtain customers, and at the same time it is beneficial for the development of enterprise.

\section{B. Purchase Intention}

Purchase intention refers to a subjective tendency that customers exhibit when purchasing products or feeling services[9].It reflects both the customer attitude and the probability of the customer paying for the product or the service. Fishbein and Ajzen (1975)[10] also believe that purchase intention is the subjective tendency of the customer to the commodity, and points out that purchase intention is an important indicator of customer behavior. Eggert and Ulaga (2002)[11] studied the factors influencing customer buying behavior, pointing out that the value recognition of goods is the most important factor in urging customers to make purchasing decisions. Jackie (2004)[12] pointed out that customer perceived value has a greater impact on purchase intention than customer satisfaction. The higher the consumer's purchase intention, the more likely they are to purchase the product. Consumers are more likely to buy, and they are more likely to buy goods. In summary, most researchers believe that customer perceived value has a significant positive impact on purchase intention. The higher the perceived value of the consumers is, consumers are more likely to purchase. Accordingly, consumers are willing to pay higher premium, and the producers will further enhance the perceived value of the consumers. Therefore, we assume that:

H1: Perceived value has a significant positive impact on purchase intention.

\section{Service Quality}

Service quality is the extent to which a service provider can meet the needs of the service recipient. The theory of 7Rs based on time and place utility was first proposed by Perrault and Russ (1974)[12] which believes that service quality can create part of product value. Then, Parasuraman (1988)[13] established the SERVQUAL scale to quantify service quality.
Cronin and Brady et al. (1997)[14] argue that service quality directly and positively affects perceived value. Based on the above research, combined with the characteristics of Fresh Hema under the new retail, the three service quality levels that affect customer perceived value and purchase intention are proposed: online service quality, offline service quality and logistics service quality. Therefore, we assume that:

H2: Service quality has a significant positive impact on perceived value

H2a: Online service quality has a significant positive impact on perceived value

H2b: Offline service quality has a significant positive impact on perceived value

H2c: Logistics service quality has a significant positive impact on perceived value

Purchase intentions are often used to test the quality of service. Boulding(1993)[15] and Alexandris (2002)[16] and others believe that service quality has a significant positive impact on purchase intention, and good services promote consumer purchases. Therefore, we assume that:

H3: Service quality has a significant positive impact on purchase intention

H3a: Online service quality has a significant positive impact on purchase intention

H3b: Offline service quality has a significant positive impact on purchase intention

H3c: Logistics service quality has a significant positive impact on purchase intention

\section{Perceived Risk}

Perceived risk refers to the possibility of consumers feeling uncertainty and adverse consequences when implementing purchases or receiving services. Bauer (1960)[17] introduced the concept of perceived risk from psychology into consumer behavior research. He believed that consumers could not predict the quality of things they bought. Mitchell (1999)[18] believes that the loss that consumers feel when they don't meet expectations is perceived risk. Zhang Tong (2011)[19] found that perceived risk not only negatively affects perceived value, but also indirectly affects purchasing willingness through perceived value. It can be seen that when consumers purchase goods in Fresh Hema, they will have an awareness of the risk of the goods, and the decrease in perceived risk will lead to an increase in perceived value. Therefore, we assume that:

H4: Perceived risk has a significant negative impact on perceived value

Mitchell (1994)[20] suggests that perceived risk is different at different stages of purchase. Jiang Minghua (2003)[21] believes that perceived risk is one of the reasons why consumers have no purchase intention. Satyabhusan Dash (2008)[22] studied that perceived risk is negatively correlated with consumer purchase intention. It can be seen from the above that the perceived risk is generated when the goods purchased by the consumer are inconsistent with the expected purchase. Since Fresh Hema uses the new method of "supermarket + catering", it will pose a greater risk to consumers' purchase intention, so it is especially important to 
reduce the perceived risk of consumers. Therefore, we assume that:

H5: Perceived risk has a significant negative impact on purchase intention

\section{MODEL CONSTRUCTION AND DATA ANALYSIS}

\section{A. Model Construction}

The relationship model between price, perceived quality, perceived value, and purchase intention was originally proposed by Dodds and Monroe(1985)[24]. Subsequently, Wood and Scheer (1996)[25] added perceived risk factors to the model and constructed a basic model based on perceived value. Based on the above literature and research, combined with the operational characteristics of Fresh Hema, the research model is shown in Figure 2.

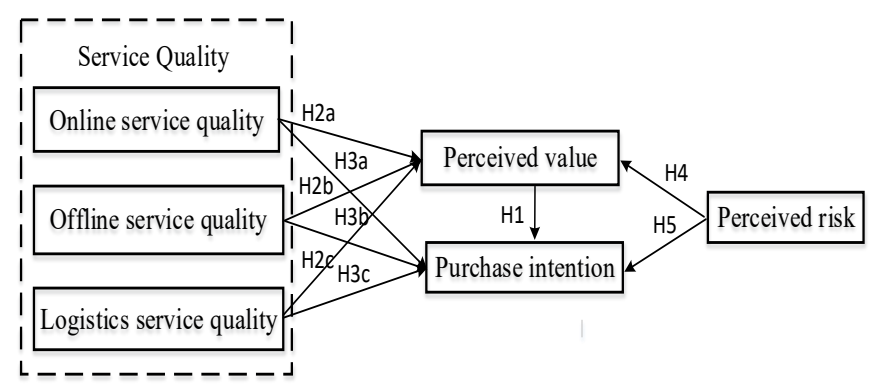

Fig. 2. Purchase Intention Influence Factor Model

\section{B. Data and Empirical Analysis}

In this article, the consumers of Fresh Hema in Wuhan are the research objects, and the questionnaires are distributed in the form of online and written. The questionnaire uses the Likert 5-point scale, and 1-5 represents "very disagree" to "strongly agree". According to the relevant scales of collection and research, combined with the characteristics of Fresh Hema to screen and perfect. After measuring the expert opinions, 24 measurement items were identified (see Table 2).

A total of 280 questionnaires were sent, of which 248 were valid questionnaires, and the recovery rate was $88.6 \%$. The number of men and women each accounted for one-half, and the age of 26 to 35 years old accounted for $52.3 \%$, indicating that the consumer group of Fresh Hema is mainly young people. The education level is mainly based on undergraduates, accounting for $63.4 \%$. The number of people with monthly income of 5,000 to 8,000 yuan is the most, accounting for $34.4 \%$, but the number below 3000 is the least, accounting for $5.2 \%$. It can be seen that Fresh Hema is the middle and highend consumption level, and the person with higher monthly income has a higher frequency of purchase.

In this study, the Cronbach's Alpha value is 0.872 , and the Barlett Test of Sphericity value is $.000<0.05$, reaching a significant level. When calculating Varimax, the specified factor loading is greater than 0.6 , so the four items A2, A6, A8, and A13 are deleted. Re-establish the reliability analysis, validity analysis and re-name the remaining 20 measurements. The results are shown in Table3. The CR values and Cronbach's Alpha of all latent variables were greater than 0.6, indicating that the scale is extremely reliable and effective.

The model uses fitting testing with AMOS 17.0 analysis software. The degree of fitting analysis of the model and the sample data is often judged by seven evaluation indicators. The results of the model fitting test are shown in Table 4.

It can be seen from Table4 that the R-squared of the research model is good, and all the indicators are within the judgment standard. It shows that the model fits the standard and does not need to be corrected. The model calculation results are shown in Figure 3. Then conduct standardized path analysis on the model. The results are shown in Table 5 and Table 6.

\section{TABLE II. MEASUREMENT ITEMS}

\begin{tabular}{|c|c|c|c|c|}
\hline Variable & Variable & Code & Measurement item & Reference source \\
\hline \multirow{13}{*}{$\begin{array}{l}\text { service } \\
\text { quality } \\
\text { (SQ) }\end{array}$} & \multirow{4}{*}{$\begin{array}{l}\text { Online } \\
\text { service } \\
\text { quality } \\
\text { (OSQ) }\end{array}$} & $\mathrm{A} 1$ & The store APP online customer service service is very good & \multirow{13}{*}{$\begin{array}{l}\text { Zeithaml et al. } \\
\text { (1988); } \\
\text { Dabholk(1994) }\end{array}$} \\
\hline & & $\mathrm{A} 2$ & The shop APP page is beautifully designed and easy to find. & \\
\hline & & $\mathrm{A} 3$ & The store APP processes orders fast & \\
\hline & & A4 & The app's comment area has a good reputation. & \\
\hline & \multirow{6}{*}{$\begin{array}{l}\text { Offline } \\
\text { service } \\
\text { quality } \\
\text { (BSQ) }\end{array}$} & A5 & The waiter in the store has a very good service attitude. & \\
\hline & & A6 & I am fond of the interior decoration style and layout. & \\
\hline & & A7 & I can dine in the dining area after purchasing food in the store,. & \\
\hline & & A8 & Waiting time for processing seafood products in the store is moderate & \\
\hline & & A9 & $\begin{array}{c}\text { The electronic label of the goods in the store makes it easy for mobile phones } \\
\text { to place orders and pay }\end{array}$ & \\
\hline & & A10 & In store self-service payment area has dedicated staff to guide & \\
\hline & \multirow{3}{*}{$\begin{array}{l}\text { Logistics } \\
\text { service } \\
\text { quality } \\
\text { (LSQ) } \\
\end{array}$} & A11 & The store fresh produce good freshness & \\
\hline & & A12 & The store's takeaway delivery service staff's attitude is very good. & \\
\hline & & A13 & The store's takeaway delivery can be delivered in time & \\
\hline \multirow{4}{*}{\multicolumn{2}{|c|}{ Perceived value (PV) }} & A14 & The store brand has a high reputation & \multirow{4}{*}{$\begin{array}{l}\text { Sweeney et al.(2001) } \\
\text { Keller, Kevin(1998) }\end{array}$} \\
\hline & & $\mathrm{A} 15$ & The store's products are cost-effective & \\
\hline & & $\mathrm{A} 16$ & Buying the store makes me feel value for money & \\
\hline & & A17 & I feel very happy to buy the store. & \\
\hline
\end{tabular}




\begin{tabular}{|c|c|c|c|}
\hline \multicolumn{4}{|c|}{ Table II, cont } \\
\hline \multirow{3}{*}{ Perceived risk (PR) } & A18 & The price of the store's goods is higher than expected & \multirow{3}{*}{$\begin{array}{c}\text { Sweeney et al(2001) } \\
\text { Chen(2007) }\end{array}$} \\
\hline & A19 & The freshness of the store's fresh produce is difficult to guarantee & \\
\hline & A20 & The goods purchased by the store APP cannot be delivered in time. & \\
\hline \multirow{4}{*}{ Purchase Intention (PI) } & A21 & I will continue to buy the store next time. & \multirow[t]{4}{*}{ Cheng(2013) } \\
\hline & A22 & I would recommend people around me to buy the store. & \\
\hline & A23 & Among similar products, I will give priority to the store. & \\
\hline & A24 & Buying the store will not make me regret & \\
\hline
\end{tabular}

TABLE III. RELIABILITY AND VALIDITY TEST RESUlts

\begin{tabular}{|c|c|c|c|c|c|c|c|c|c|}
\hline $\begin{array}{c}\text { Latent } \\
\text { variable }\end{array}$ & $\begin{array}{c}\text { Observation } \\
\text { variable }\end{array}$ & $\begin{array}{c}\text { Standard } \\
\text { factor load }\end{array}$ & CR & $\begin{array}{c}\text { Cronbach's } \\
\text { Alpha }\end{array}$ & $\begin{array}{c}\text { Latent } \\
\text { variable }\end{array}$ & $\begin{array}{c}\text { Observation } \\
\text { variable }\end{array}$ & $\begin{array}{c}\text { Standard } \\
\text { factor load }\end{array}$ & CR & $\begin{array}{c}\text { Cronbach's } \\
\text { Alpha }\end{array}$ \\
\hline \multirow{3}{*}{ OSQ } & OSQ1 & 0.791 & \multirow{3}{*}{0.828} & \multirow{3}{*}{0.827} & \multirow{2}{*}{ LSQ } & LSQ1 & 0.737 & \multirow{2}{*}{0.804} & \multirow{2}{*}{0.803} \\
\hline & OSQ2 & 0.825 & & & & LSQ2 & 0.783 & & \\
\hline & OSQ3 & 0.741 & & & \multirow{4}{*}{ PV } & PV1 & 0.801 & \multirow{4}{*}{0.838} & \multirow{4}{*}{0.838} \\
\hline \multirow{4}{*}{ BSQ } & BSQ1 & 0.814 & \multirow{4}{*}{0.891} & \multirow{4}{*}{0.889} & & PV2 & 0.763 & & \\
\hline & BSQ2 & 0.861 & & & & PV3 & 0.811 & & \\
\hline & BSQ3 & 0.847 & & & & PV4 & 0.796 & & \\
\hline & BSQ4 & 0.835 & & & \multirow{4}{*}{ PI } & PI1 & 0.804 & \multirow{4}{*}{0.882} & \multirow{4}{*}{0.878} \\
\hline \multirow{3}{*}{ PR } & PR1 & 0.820 & \multirow{3}{*}{0.869} & \multirow{3}{*}{0.868} & & $\mathrm{PI} 2$ & 0.841 & & \\
\hline & PR2 & 0.828 & & & & PI3 & 0.832 & & \\
\hline & PR3 & 0.834 & & & & PI4 & 0.814 & & \\
\hline
\end{tabular}

The following conclusions can be drawn from the table:(1)Perceived value has a significant positive correlation with purchase intention. Explain that the greater the perceived value of Fresh Hema consumers, the stronger the willingness to purchase.(2)Quality of service is positively related to perceived value and willingness to purchase. Among them, the positive correlation between offline quality service and perceived value is the most significant, with a path coefficient of 0.63. Explain that the consumers of Fresh Hema feel very good about the service quality of offline stores, and the evaluation is very high. Since there is only one Fresh Hema in Wuhan, most consumers cannot experience the 30-minute delivery service within $3 \mathrm{~km}$. Therefore, the impact of logistics service quality on customers' perceived value and purchase intention is generally significant.(3)Perceived risk is negatively correlated with perceived value and purchase intention. It shows that the lower the perceived risk of consumers, the higher probability of purchase. Among them, the impact of perceived risk on perceived value is generally significant. It shows that consumers perceive the high prices of some commodities, but good shopping experience they would choose to purchase in the store.

TABLE IV. Model Fitting Test Results

\begin{tabular}{|c|c|c|}
\hline Fitting index & Adapted standard & Model fit \\
\hline $\mathrm{x}^{2} / \mathrm{df}$ & $1<\mathrm{x}^{2} / \mathrm{df}<3$ & 1.872 \\
\hline RMR (root mean square residual) & $<0.05$ & .028 \\
\hline $\begin{array}{l}\text { RMSEA (root mean square error } \\
\text { of approximation) }\end{array}$ & $<0.08$ & .032 \\
\hline GFI (goodness of fit index) & $>0.9$ & .937 \\
\hline NFI (normed fit index)c & $>0.9$ & .921 \\
\hline IFI(Incremental fit index) & $>0.9$ & .978 \\
\hline CFI (comparative fit index) & $>0.9$ & .975 \\
\hline
\end{tabular}




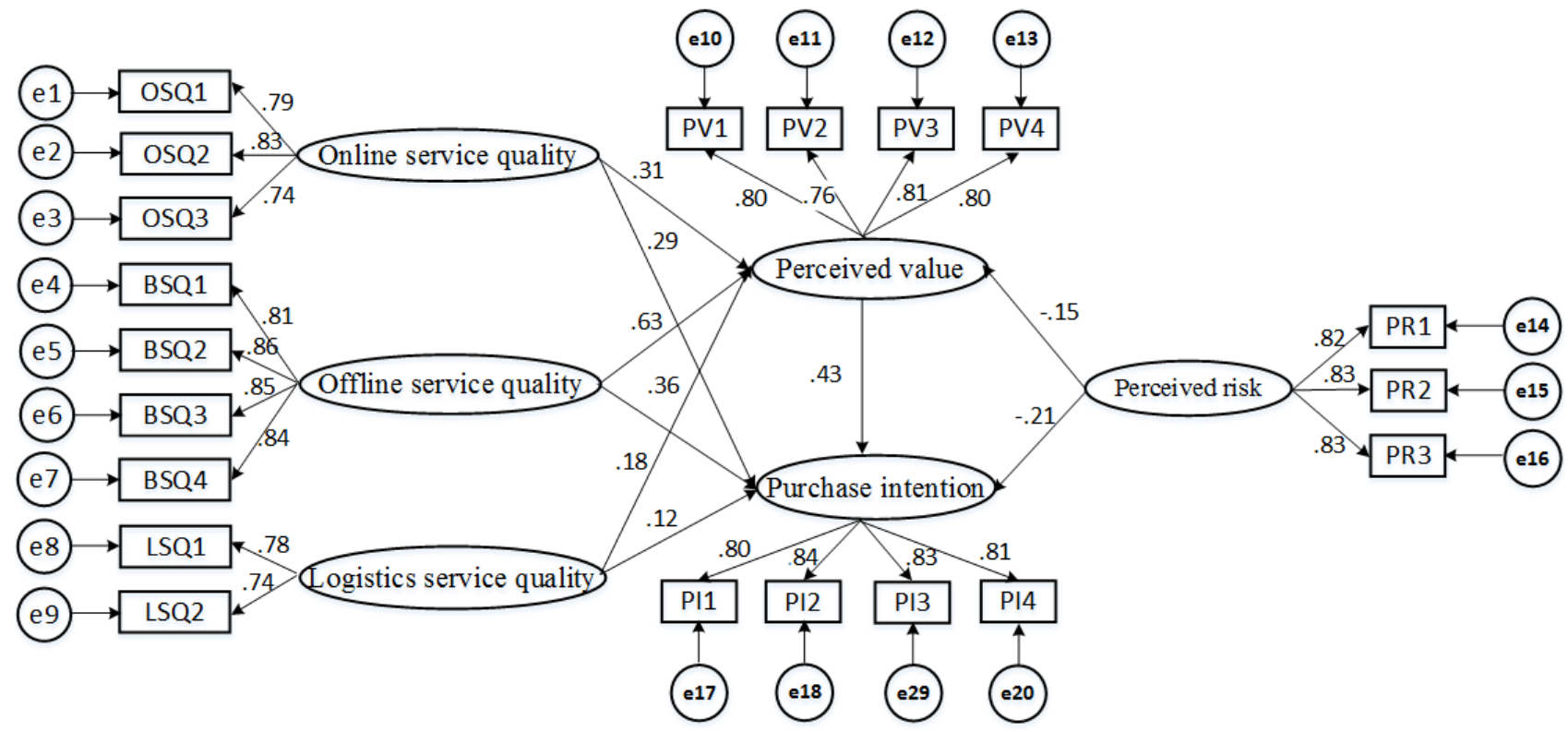

Fig. 3. Relationship Between Model Variables

TABLE V. Path Coefficient Between Each Latent Variable

\begin{tabular}{|l|c|c|c|c|}
\hline \multicolumn{1}{|c|}{ Path } & $\begin{array}{c}\text { Standardized Path } \\
\text { Coefficient }\end{array}$ & S.E. & C.R. & P \\
\hline Perceived value $\rightarrow$ purchase intention & 0.434 & 0.070 & 6.694 & $* * *$ \\
\hline Online service quality $\rightarrow$ perceived value & 0.314 & 0.069 & 5.261 & $* * *$ \\
\hline Offline service quality $\rightarrow$ perceived value & 0.631 & 0.068 & 10.132 & $* * *$ \\
\hline Logistics service quality $\rightarrow$ perceived value & 0.183 & 0.059 & 2.491 & $*$ \\
\hline Online service quality $\rightarrow$ purchase intention & 0.291 & 0.064 & 4.934 & $* * *$ \\
\hline Offline quality of service $\rightarrow$ purchase intention & 0.363 & 0.079 & 5.696 & $* * *$ \\
\hline Logistics service quality $\rightarrow$ purchase intention & 0.121 & 0.053 & 2.256 & $*$ \\
\hline Perceived risk $\rightarrow$ perceived value & -0.153 & 0.062 & -2.461 & $*$ \\
\hline Perceived risk $\rightarrow$ purchase intention & -0.218 & 0.073 & -3.027 & $* * *$ \\
\hline
\end{tabular}

Note: $*$ is $\mathrm{P}<0.05$, indicating that it is generally significant.

$* *$ is $\mathrm{P}<0.01$, indicating that it is significant. $* * *$ is $\mathrm{P}<0.001$, indicating that it is very significant.

TABLE VI. Summary OF Hypothesis Test Results

\begin{tabular}{|c|c|c|}
\hline Hypothesis & Assumed Content & Test Result \\
\hline H1 & Perceived value has a significant positive impact on purchase intention & support \\
\hline H2 & Service quality has a significant positive impact on perceived value & support \\
\hline H2a & Online service quality has a significant positive impact on perceived value & support \\
\hline H2b & Offline quality of service has a significant positive impact on perceived value & support \\
\hline H2c & Logistics service quality has a significant positive impact on perceived value & support \\
\hline H3 & Service quality has a significant positive impact on purchase intention & support \\
\hline H3a & Online service quality has a significant positive impact on purchase intention & support \\
\hline H3b & Offline quality of service has a significant positive impact on purchase intention & support \\
\hline H3c & Logistics service quality has a significant positive impact on purchase intention & support \\
\hline H4 & Perceived risk has a significant negative impact on perceived value & support \\
\hline H5 & Perceived risk has a significant negative impact on purchase intention & support \\
\hline
\end{tabular}




\section{CONCLUSIONS}

According to the research conclusions, this article proposes an optimization strategy for Fresh Hema in the existing business strategy, to improve service quality and perceived value, reduce perceived risks, and increase customer's purchase intention. The specific optimization strategy is as follows: (1) Optimize in-store layouts to enhance the user experience. In order to enhance the consumer experience, a storage cabinet can be set up in the store to f store luggage items. The seafood processing area has a special waiting area, which not only improves the satisfaction of waiting customers, but also reduces the congestion of the aisles. Place the dining area in the edge area of the supermarket to give consumers a quiet dining environment. (2) Improve service quality and reduce perceived risk. For online services, merchants can post details of each item and offer on the app in time to reduce the perceived risk of consumers. The store can establish a customer service center to provide timely information on consumer goods, orders, etc. If the takeaway cannot be delivered to the consumer within the specified time, the perceived risk will increase. If real-time location tracking can be performed for the sale, consumers can appropriately reduce the perceived risk by observing the dynamics of the purchased goods.

There are still deficiencies in this article. The selected research indicators fail to cover all the factors affecting the purchasing intention of the consumers. In addition, there are fewer samples of the questionnaire. When conditions permit, consumers from Fresh Hema nationwide can be interviewed to establish a comprehensive system of factors affecting purchase intention.

\section{ACKNOWLEDGMENT}

This work was supported by the National Natural Science F oundation of China (71501147, 71601150), Cultivation plan pr oject for young scholar at Wuhan University of Science and Te chnology (250089) and Centerof Service Science and Engineer ing at Wuhan University of Science and Technology (CSSE20 17GB03).

\section{REFERENCES}

[1] Opinions of the General Office of the State Council on Promoting the Innovation and Transformation of Entity Retail [J]. East China Science and Technology, 2017 (01):45.

[2] Cao Yu, Liu Zhili. Fresh Hema, fresh industry "new retail" practitioners[J]. Shanghai Informatization, 2017(06):23 26.

[3] Feng Shanshan. Read new retail [J]. CFO, 2017 (19):18 26.

[4] Wang Yuanyuan, Shao Dan, Cui Zhaoqian. On the effect and improvement strategy of the offline mode of Fresh Hema online and offline mode [J]. Technological horizon,2017(19):135 136.

[5] Zeithaml, V.A. Consumer perceptions of price, quality, and value: A means-end model and synthesis of evidence. Journal of Marketing, 1988,52:2 22.

[6] Woodruff. Customer value: the next source for competitive advantage [J]. Journal of the Academy of Marketing Science, 1997, 25: 139 153.

[7] Fan Xiucheng, Luo Haicheng. Analysis on the Competitiveness of Service Enterprises Based on Customer Perceived Value [J]. Nankai Management Review, 2003(6).

[8] Wang Xiqiu. Research on Customer Value and Its Evaluation Method [J]. Nankai Management Review, 2005 (8).
[9] Dodds, W .B. , Grewal, D. \&Monroe, K.B.. The Effects of price, Brand and Store Information on Buyers' Product Evaluation [J]. Joumal of MarketingResearch,1991,28 (3)307 219.

[10] Fishbein, M. and Ajzen, I. Belief, Attitude, Intention and Behavior: An Introduction to Theory and Research. Addison-Wesley Pub. Co., Reading, 1975.

[11] Eggert A. \& Ulaga, W.. Custemer Perceived Value: A Substitute for Satisfaction in Business Markets[J]. The Journal of Business \& Industrial Marketing, 2002,17(3)107 118.

[12] Jacke,L.M .\&Tam. Customer satisfaction, Service Quality and Perceived Value: An Integrative Model [J] .Joumal of Marketing management,2004,20: 897 917.

[13] Perrault W D, Russ F. Physical distribution service: A neglected aspect of marketing management [J]. MSU Business Topics, 1974, 22(2): 37 45.

[14] Parasuraman, A., Zeithaml, V. \& Berry, L. SERVQUAL: A MultipleItem Scale for Measuring Consumer Perceptions of Service Quality [J].Journal of Retailing, 2002, 64(1):12 40.

[15] Cronin J J Jr, Brady MK, Brand R R, Hightower R Jr, Shemwell D J. A cross-sectional test of the effect and conceptualization of service value [J]. The Journal of Services Marketing, 1997, 11(6): 375 391 .

[16] Boulding, W., Kalra, A., Richard, S., \& Zeithaml, V. A. A dynamic process model of service quality: From expectations to behavioral intentions. Journal of Marketing Research, 1993,30(1), $7 \sim 27$.

[17] Alexandris, K., Dimitriadis, N., \& Markata, D. Can perceptions of service quality predict behavioral intentions? An exploratory study in the hotel sector in Greece. Managing Service Quality, 2002,12(4), 224 231.

[18] Bauer, R.A. Consumer Behavior as Risk Taking. In: Hancock, R.S., Ed., Dynamic Marketing for A Changing World, American Marketing Association, Chicago, 1960.

[19] Mitchell V W. Consumer perceived risk: conceptualizations and models[J].European Journal of Marketing,1999,33(1/2):163 195.

[20] Zhang Tong. Bank Personal Finance Customer Identification Matrix Construction and Empirical Research [J]. Journal of Shanxi University of Finance and Economics,2011(11).

[21] Mitchell V W, Boustani P. A preliminary investigation into pre-and post-purchase risk perception and reduction[J].European Journal of Marketing, 1994,28(1):56 71.

[22] Jiang Minghua. The impact of "do not want" on consumers' purchase intention and its marketing significance [J]. Journal of Central University of Finance and Economics, 2003 (8).

[23] Satyabhusan Dash, Saji K.B. The role of consumer self-efficacy and Website social-presence in customers' adoption of B2C online shopping an empirical study in the India context [J] .Journal of International Consumer Marketing, 2008,20(2):33 48.

[24] Dodds W B, Monroe K B. The Effect of Brand and Price Information on Subjective Product Evaluations [J]. Advances in Consumer Research, 1985, 12( 1): 85 90.

[25] Wood C M, Scheer L K. Incorporating Perceived Risk into Models of Consumer Deal Assessment and Purchase Intent [J]. Advances in Consumer Research,1996,23(1):309 404. 